\title{
Inventarisasi Jenis-jenis Rumput di Jalur Pendakian Gunung Ungaran
}

\author{
Muhammad Hasiibun Nuhaa ${ }^{*}$, Lianah², Baiq Farhatul Wahidah ${ }^{2}$ \\ 1Pendidikan Biologi UIN Walisongo Semarang, \\ 2 Biologi UIN Walisongo Semarang \\ Jalan Prof. Dr. Hamka Km. 03-05 Ngaliyan, Kota Semarang, Indonesia \\ *Email: asibnuha@gmail.com
}

\begin{abstract}
MountUngaranhasveryvariedvegetationwhichincludesgrassplants. Thepurpose of this study was to find out the types of Poaceae family grass found on the Mount Ungaran hiking path. This type of research is a qualitative research field. The object of the research is the types of grass belonging to the family Poaceae. Data collection techniques used in this study were observation and characterization. The results of the study obtained 29 species from 23 genera.
\end{abstract}

Key words : grass, Mount Ungaran, Poaceae.

\section{Pendahuluan}

Indonesia merupakan negara kepulauan yang terletak di kawasan tropis antara dua benua (Asia dan Australia) dan dua Samudera (Samudera Hindia dan Samudera Pasifik) yang terdiri atas sekitar 17.500 pulau dengan panjang garis pantai sekitar $95.181 \mathrm{~km}$. Luas wilayah Indonesia hanyasekitar 1,3\% dari luas bumi, namun mempunyai tingkat keberagaman kehidupan yang sangat tinggi (Kusmana, 2015).

Indonesia memiliki potensi keanekaragaman spesies yang tinggi, diperkirakan mempunyai 19\% tanaman gymnospermae, $11 \%$ tanaman berbunga, $13 \%$ tumbuhan paku, dan 9\% tumbuhan lumut dari semua jenis tumbuhan yang terdapat di dunia (Amir, 1989).

Rumput merupakan kelompok tumbuhan berbiji yang jumlah anggota jenisnya besar, kurang lebih 620 marga yang terdiri atas 10.000 jenis rumput ada di dunia ini. Semua orang mengenal kelompok rumput dari bentuk daunnya yang memikat, akan tetapi sebenarnya tidak semuanya tumbuhan yang berdaun memita termasuk suku rumputrumputan. Rumput memiliki manfaat dalam kehidupan diantaranya sebagai pakan ternak, atap rumah atau pura dan tanaman hias (LIPI,
1980).

Keragaman tumbuhan menyebabkan seseorang sulit untuk menentukan jenis dari tumhuhan, dan sering kali seseorang 65 mukan tumbuhan akan tetapi tidak mengetahui nama dan jenisnya. Untuk mengetahui identitas tumbuhan, langkah pertama yang harus dilakukan adalah mengenali tumbuhan tersebut (Juhriah, 2014).

Inventarisasi merupakan serangkaian kegiatan untuk melakukan pendataan dan mendokumentasikannya pada suatu waktu tertentu (Sugiama, 2013). Invetarisasi ini merupakan

suatukegiatanuntukmengelompokkandatama upunmengelompok-

kansuatutumbuhanpadasuatu wilayah.

Area pegunungan merupakan suatu tempat yang menarik untuk melakukan penelitian. Terdapat banyak sekali jenis vegetasi yang dapat ditemukan ditempat tersebut. Tanah yang subur serta udara yang sejuk menjadi factor yang membuat kawasan tersebut banyak ditumbuhi tanaman, salah satunya adalah rumput.Gunung Ungaran merupakan salah satu gunung yang berada di kabupaten Semarang, Jawa Tengah, Indonesia yang terletak di koordinat $7^{\circ} 10^{\prime} 48^{\prime \prime} \mathrm{LS}$ 
$110^{\circ} 19^{\prime} 48^{\prime \prime} \mathrm{BT} / 7,18^{\circ} \mathrm{LS} \quad 110,33^{\circ} \mathrm{BT}$ dengan ketinggian $2050 \mathrm{mdpl}$. Gunung tersebut mempunyai komposisi keanekaragaman jenis flora yang sangat bervariasi dan umumnya dapat dibedakan dari kondisi dataran rendah yang ada di sekitarnya karena batas ketinggian yang jelas (Aristria, 2014).

Inventarisasi tanaman rumput pada suatu wilayah sangat diperlukan dalam menunjang kelestarian sumber daya hayati di Ungaran khususnya, dan di Indonesia pada umumnya.

\section{Metode}

Disain yang digunakan yaitu sequential exploratory. Sequential exploratory adalah penelitian yang dimulai dengan mengeksplorasi data dengan pendekatan kualitatif dan dianalisis serta dikembangkan dengan teori kemudian dilengkapi dengan pendekatan kuantitatif. Langkah-langkah yang akan ditempuh dalam pengambilan data untuk penelitian ini yaitu:

1. Penentuan lokasi: Lokasi penelitian ini dilakukan di jalur pendakian Gunung Ungaran melalui jalurPromasan.

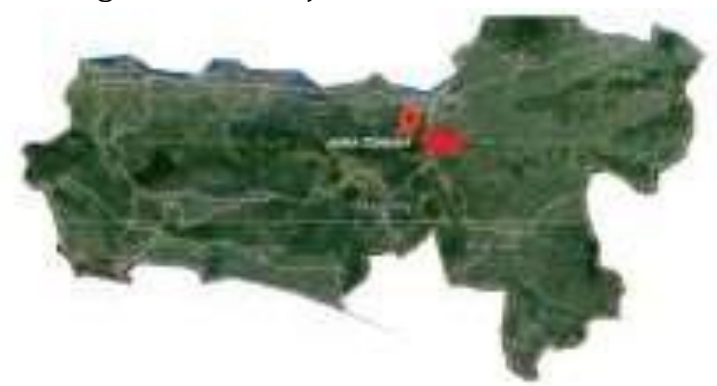

Gambar 1. Peta Jawa Tengah

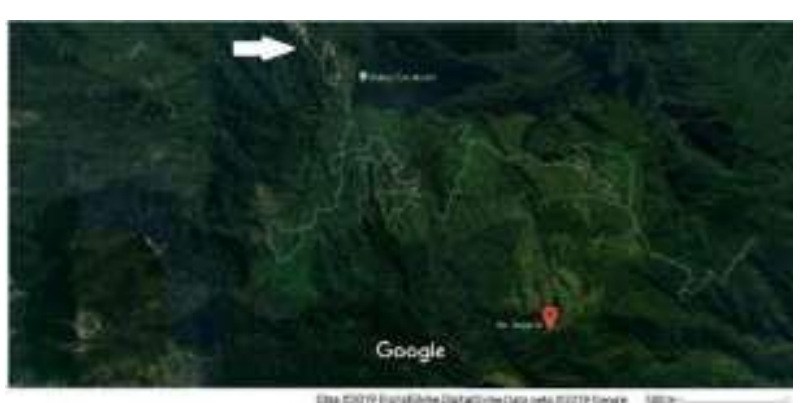

Gambar 2. Peta Gunung Ungaran

2. Menyiapkan alat yang akan digunakan dalampenelitian.

3. Pengambilan data dilakukan dengan cara metode jelajah sehingga dimungkinkan dapat memperoleh banyaksampel

4. Dokumentasi dan mengambil sampel dari lapangan. Dokumentasi dilakukan dengan pengambilan dokumen baik berupa gambar ataupunvideo.

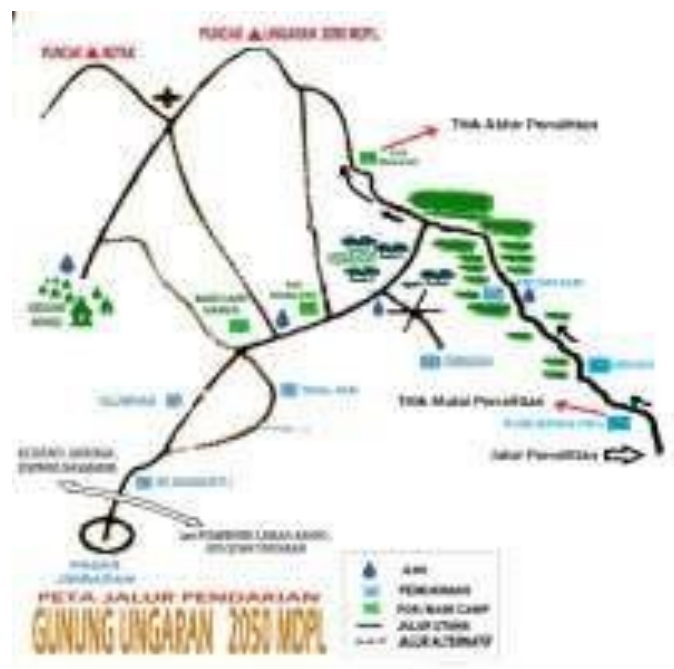

Gambar 3. Jalur Pendakian dan Penelitian Gunung Ungaran

Teknik pengumpulan data secara keseluruhan menggunakan teknik observasi, kajian dokumen, dan teknik karakterisasi. Penyajian data dalam penelitian kualitatif bias dilakukan dalam bentuk uraian singkat, bagan, hubungan antara kategori, dan dengan teks yang bersifat naratif (Sugiyono, 2016). Penyajian data pada penelitian ini berupa tabel hasil inventarisasi jenis-jenisrumput.

\section{Hasil dan Pembahasan}

Hasil penelitian di jalur pendakian Gunung Ungaran yang terletak di koordinat $7^{\circ} 10^{\prime} 48^{\prime \prime} \mathrm{LS}$ $110^{\circ} 19^{\prime} 48^{\prime \prime} \mathrm{BT} / 7,18^{\circ} \mathrm{LS}$ $110,33^{\circ} \mathrm{BT}$, di mulai dari dusun Ngesrep Balong hingga Pos bukaan pada ketinggian 1030-1500 m.dpl dan di dokumentasi menggunakan kamera canon D3000 terdapat 29 spesies rumput famili Poaceae yang ditemukan. Data yang diperoleh selanjutnya didiskripsikan secara morfologi dan diamati 
melalui mikroskop.

Rumput yang ditemukan terdiri dari beragam jenis rumput yang memiliki karakter morfologi berbeda terutama pada bagian perbungaannya. Berikut jenis-jenis rumput yang ditemukan di jalur pendakian Gunung Ungaran.

Tabel 3. Data Jenis-jenis Rumput

\begin{tabular}{|c|c|c|}
\hline No. & Nama Lokal & Nama Ilmiah \\
\hline 1 & Alang-alang & Imperata cylindrica \\
\hline 2 & Blembem Watu & Ischaemum barbatum \\
\hline 3 & Jagung & Zea mays \\
\hline 4 & Jajagoan & Echinochloa crus-galli \\
\hline 5 & Jelai & Coix lacryma-jobi \\
\hline 6 & Jukut Gebluk & Eragrostis nigra \\
\hline 7 & $\begin{array}{l}\text { Jukut Jajagoan } \\
\text { Leutik }\end{array}$ & Echinochloa colonum \\
\hline 8 & Jukut Jampang & Eleusine indica \\
\hline 9 & Jukut Kakasuran & Isachne globosa \\
\hline 10 & Jukut Pait & Axonopus compressus \\
\hline 11 & Jukut Piit & Eragrostis unioloides \\
\hline 12 & Kaso Beurit & Thysano laena maxima \\
\hline 13 & Kembang Goyang & Chloris barbata \\
\hline 14 & Lamisan & Oplismenus compositus \\
\hline 15 & Lamisan bulu & Oplismenus burmani \\
\hline 16 & Lamuran & Eulalia amaura \\
\hline 17 & $\begin{array}{l}\text { Lamuran } \\
\text { Menjangan }\end{array}$ & Dichantium caricosum \\
\hline 18 & Nyenyerean & Sporobolus berteroanus \\
\hline 19 & $\begin{array}{l}\text { Rumput } \\
\text { Benggala }\end{array}$ & Panicum maximum \\
\hline 20 & $\begin{array}{l}\text { Rumput Emprit- } \\
\text { empritan }\end{array}$ & Eragrostis amabilis \\
\hline 21 & Rumput Gajah & Pennisetum purpureum \\
\hline 22 & $\begin{array}{l}\text { Rumput merak- } \\
\text { merakan }\end{array}$ & Themeda arguens \\
\hline 23 & Rumput Natal & Rhynchelytrum roseum \\
\hline 24 & $\begin{array}{l}\text { Rumput } \\
\text { Perimping }\end{array}$ & Themeda gigantean \\
\hline 25 & $\begin{array}{l}\text { Rumput Pring- } \\
\text { pringan Cilik }\end{array}$ & Ottochloa nodosa \\
\hline 26 & Rumput Sawang & $\begin{array}{l}\text { Pennisetum } \\
\text { macrostachyum }\end{array}$ \\
\hline 27 & $\begin{array}{l}\text { Rumput Uler- } \\
\text { uleran }\end{array}$ & Setaria geniculate \\
\hline 28 & Sereh & Andropogon nardus \\
\hline 29 & Suduk Gangsir & Digitaria ciliaris \\
\hline
\end{tabular}

\section{Simpulan}

Jenis-jenis rumput yang ditemukan di jalur pendakian Gunung Ungaran terdiri dari 29 spesies yang termasuk dalam 1 famili Poaceae.

\section{Daftar Pustaka}

Akbar, Sa'dun. 2013. Instrumen Perangkat Pembelajaran. Bandung: PT Remaja Rosda Karya.

Amir. 1989. Studi Potensi Tumbuhan Obat di Kawasan Hutan Pendidikan Gunung Walat. Karya Ilmiah.Jurusan Konservasi Sumber daya Hutan Fakultas Kehutanan Institut Pertanian Bogor.

Aristria,D.,Perwati,L.K.,\&Wiryani,E.2014.Kean ekaragamanMarchantiophytaEpifitZona Montana di Kawasan Gunung Ungaran, Jawa Tengah. Bioma: Berkala Ilmiah Biologi, 16(1), 26-32. https://ejournal.undip.ac.id/, diakses pada tanggal 23 Juli2018.

Ferianita, Melati F. 2007. Metode Sampling Bioekologi. Jakarta: Bumi Aksara.

Juhriah. DKK, 2014. Sistematika Tumbuhan Tinggi. Makassar: FMIPA Universitas Hasanuddin.

Kusmana, C., \& Hikmat, A. 2015. Keanekaragaman hayati flora di Indonesia. Jurnal Pengelolaan Sumberdaya Alam dan Lingkungan (Journal of Natural Resources and Environmental Management), 5(2), 187. http://103.10.105.67/index.php/jpsl/ar ticle/view/10962, diaksespada tanggal 2 Juni 2018.

LIPI. 1980. Jenis Rumput Dataran Rendah. Bogor: Lembaga Biologi Nasional.

Moleong, Lexy J.. 2013. Metodologi Penelitian Kualitatif Bandung: PT. Remaja Rosdakarya. Sugiama, A.G. 2013. Manajemen Aset Pariwisata. Bandung: Guardaya Intimarta. Bandung: Alfabeta. 